\title{
接着系あと施エアンカーの 耐アルカリ性評価方法に関する検討
}

\author{
富山 禎仁 1 ・西崎 到2 \\ 1正会員 国立研究開発法人士木研究所 材料資源研究グループ（テ305-8516 茨城県つくば市南原1-6) \\ E-mail: tomiyama@pwri.go.jp \\ 2正会員 国立研究開発法人士木研究所 材料資源研究グループ（テ305-8516 茨城県つくば市南原1-6) \\ E-mail: nisizaki@pwri.go.jp
}

\begin{abstract}
本報では, コンクリート内部の高アルカリ環境下における接着系あと施工アンカーの劣化挙動と, その 試験評価方法について検討した結果を報告する. ACI 355.4-11を参考に, 水酸化カリウム水溶液への浸せ きによる接着剤の力学特性の変化を, アンカーのスライス試験片の押抜試験により評価した。 また, 浸せ き前後のアンカー接着剤について赤外線分光分析を行い, その化学構造の変化を調べた. その結果, $40^{\circ} \mathrm{C}$ で4000時間浸せきした場合においても，接着強さの明確な低下は認められなかった，一方，接着剤の樹脂 成分である不飽和ポリエステルは，アルカリによる加水分解が進行しつつあることが明らかとなった. 加 水分解の程度は環境液の温度が高い方が大きく，また，浸せき時間が長くなるにつれ，接着剤表面から内 部へ徐々に進行する挙動を示した。
\end{abstract}

Key Words : post-installed adhesive anchor, durability, immersion test, alkaline fluid, punch test

\section{1. はじめに}

接着系あと施工アンカー（以降，接着系アンカーと称 す）は比較的容易に定着が可能なことから，土木構造物 においても付帯施設や而震補強などに広く用いられてい る.しかし，コンクリート内部におけるこれらの長期的 な挙動については，十分に解明されていないのが現状で あり，さらなるデータの充実が必要である.

そこで本研究では，コンクリート内部の高アルカリ環 境下で生じるアンカー接着剤の劣化挙動を明らかにする ことと，その適切な評価方法を提案することを目的とし て，接着系アンカーのアルカリ浸せき試験を行った。 そ の一部として，接着系アンカーの試験方法の一つである ACI 355.4-11)を参考に，水酸化カリウム（以下， $\mathrm{KOH}$ 称す）水溶液への浸せきによるアンカー接着剤の力学特 性の変化を，押抜試験によって評価した。

本報では，スライス試験片の厚さや押抜試験における 反力板の開孔部径等を変えて実験を行い，破壊形態や最 大押抜荷重に及ぼす試験条件の影響について検討した結 果と，浸せき前後のアンカー接着剤について赤外線分光 分析を行い，接着剂の樹脂成分の化学構造変化から， $\mathrm{KOH}$ 水溶液による接着剤の劣化挙動について検討した 結果について報告する.

\section{2. 実験方法}

(1) 試験片

\section{a) 接着系あと施エアンカー}

接着系アンカーは，製品の形態や施工方法，使用され ている接着剤樹脂の種類等が異なる，さまざまな製品が 市販されている2。本研究ではこれらの中から，ガラス 製カプセルに接着剤（主剤，硬化剤）と骨材とが封入さ れた「カプセル方式」の製品を用いた。このカプセルは, ドリル孔に挿入し回転・打撃を与えて施工する「回転・ 打撃型」である. 市販の接着系アンカーに用いられてい る代表的な樹脂には不飽和ポリエステル樹脂，エポキシ 樹脂，ビニルエステル樹脂等がある.このうち，不飽和 ポリエステル樹脂は，構成分子の主鎖中に多数のエステ ル結合を有していることから，他の樹脂と比べて，環境 の影響により加水分解を生じやすいことが知られている. このため, 本研究では不飽和ポリエステル樹脂をモデル ケースとして取り上げ，アンカー接着剤の耐アルカリ性 評価方法について検討することとした，不飽和ポリエス テル樹脂にはオルソフタル酸系，イソフタル酸系，ビス フェノール系, ヘット酸系等のグレードがあり，要求性 能に応じて使い分けられている3). 本研究では, これら の中でも耐薬品性に優れるとされている，ビスフェノー 
ル系不飽和ポリエステル樹脂を用いた製品を実験に供し た. 実験に用いた接着系アンカーの製品規格における寸 法，強度を表-1に示寸.

\section{b) 母材コンクリート}

試験片の母材となるコンクリートは, 内径 194 mm, 高さ150 mmの硬質塩化ビニル厚肉管（管厚 $11 \mathrm{~mm}$ ）を型 枠にして打設した。 母材コンクリートの配合を表-2に示 す. セメントには普通ポルトランドセメントを用い，粗 骨材の最大寸法は $20 \mathrm{~mm}$ とし。. 母材コンクリートは打 設後, 型枠ごとビニール袋内に封入し，材齢28日目まで $20^{\circ} \mathrm{C}$ 環境下で封緘養生した。 その後, 試験に用いるま では常温の大気中で養生した.

材齢28日目における圧縮強度は約 $23 \mathrm{~N} / \mathrm{mm}^{2}$ であり，こ れは ACI 355.4-11で規定される母材コンクリートの圧縮 強度2500〜 4000 psi（17.2〜27.6MPa）に準拠している.

\section{c) 試験片作製方法}

製造メーカーが指定する方法により，母材コンクリー 卜に接着系アンカーを施工した. 材齢約15週の母材コン クリート上面中央に直径 $14.5 \mathrm{~mm}$ ，深さ100 $\mathrm{mm}$ のを八 ンマードリルで設けてアンカーのカプセルを挿入し，先 端を斜め $45^{\circ}$ にカットした全ねじボルト（M12）を挿入 しながら，カプセルに回転・打撃を与えて施工した。

削孔やボルト挿入の際には，ハンマードリルやボルト を支持するガイド等は用いなかったため，ドリル孔やボ ルトの傾き，ドリル孔に対するボルトの偏心が生じるケ 一スが散見された，そこで，図-1に示す方法で二軸傾斜 計を用い，母材コンクリート上面の垂線に対するボルト の傾きを求めた．図-2は，接着系アンカーを施工した60 個の供試体についてボルトの傾きを計測し，ヒストグラ ムとして整理した結果である. 供試体60個のボルトの傾 きの平均值は $1.3^{\circ}$ (最小 $0^{\circ} \sim$ 最大 $\left.3.5^{\circ}\right)$, 標準偏差は $0.8^{\circ}$, 変動係数は0.61であった. ACI 355.4-11では, 母材コンク リートの削孔工程においてハンマードリルの手持ち作業

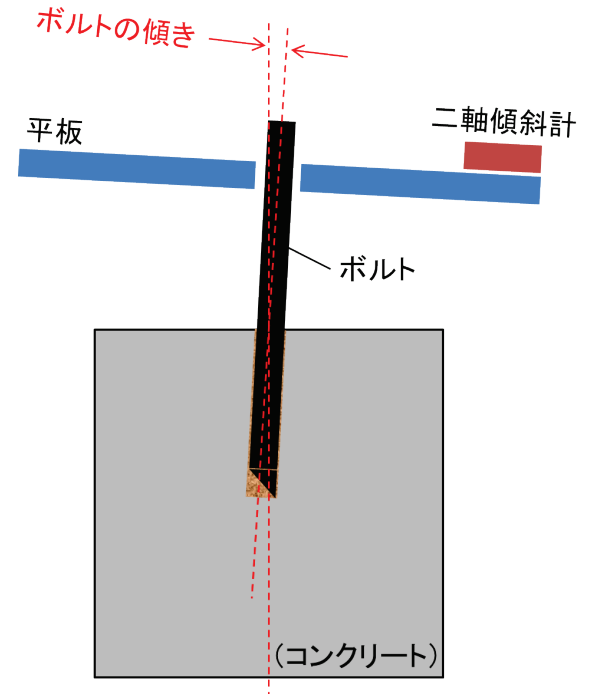

図-1 二軸傾斜計を用いたボルトの傾きの計測方法

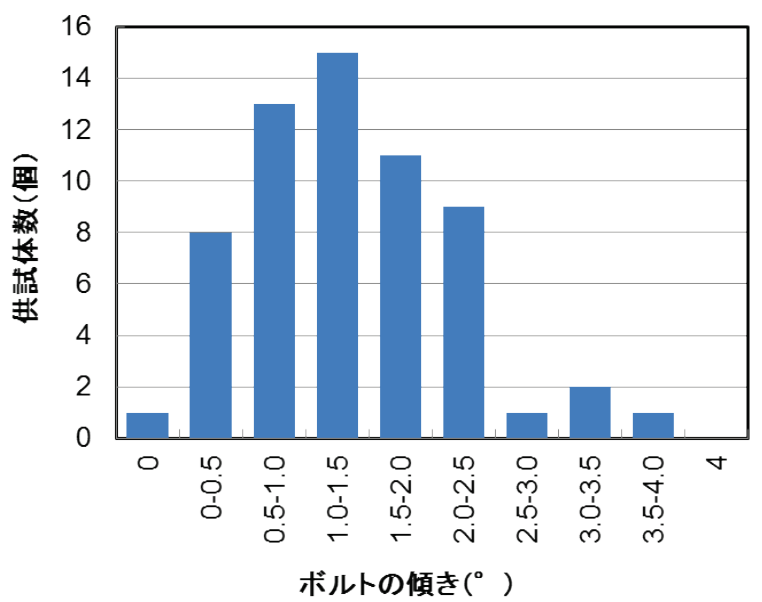

図-2 60個の供試体におけるボルトの傾きの分布

表-1 実験に用いた接着系あと施工アンカーの寸法と強度（製造メーカーの技術資料より）

\begin{tabular}{|c|c|c|c|c|c|c|c|}
\hline $\begin{array}{c}\text { 外径 } \\
(\mathrm{mm})\end{array}$ & $\begin{array}{c}\text { 長さ } \\
(\mathrm{mm})\end{array}$ & $\begin{array}{c}\text { 容量 } \\
(\mathrm{mL})\end{array}$ & アンカー筋 & $\begin{array}{c}\text { ドリル径 } \\
(\mathrm{mm})\end{array}$ & $\begin{array}{c}\text { 削孔長 } \\
(\mathrm{mm})\end{array}$ & $\begin{array}{c}\text { 最大引張 } \\
\text { 強度 }(\mathrm{kN})\end{array}$ & $\begin{array}{c}\text { 付着強さ } \text { N }^{2} \\
\mathrm{~N} / \mathrm{mm}^{2}\end{array}$ \\
\hline 13 & 100 & 10 & $\mathrm{M} 12^{* 1}$ & 14.5 & 100 & 57.4 & 14.3 \\
\hline
\end{tabular}

※1: SUS304 全ねじボルト 先端斜め $45^{\circ}$ カット

$※ 2$ : 有効付着長 (削孔長一カット部長) により算出

表-2母材コンクリートの配合

\begin{tabular}{|c|c|c|c|c|c|c|c|}
\hline \multirow{2}{*}{$\begin{array}{c}\text { 水セメント比 } \\
\text { (\%) }\end{array}$} & \multirow{2}{*}{$\begin{array}{c}\text { 細骨材率 } \\
\text { (\%) }\end{array}$} & \multicolumn{4}{|c|}{ 単位量 $\left(\mathrm{kg} / \mathrm{m}^{3}\right)$} & \multirow{2}{*}{ 混和剤A } & \multirow{2}{*}{ 混和剤B } \\
\hline & & 水 & セメント & 細骨材 & 粗骨材 & & \\
\hline 70 & 47 & 163 & 23.3 & 87.4 & 1001 & セメント $\times 0.25 \%$ & セメント $\times 0.003 \%$ \\
\hline
\end{tabular}


を許容しており，その際のドリル孔の傾きは最大で6゚ま でと規定している，直径 $14.5 \mathrm{~mm}$, 深さ100 mmのドリル 孔内では，先端を斜め45にカットしたM12ボルトは最 大で1.6程度傾く可能性がある. 計測したボルトの傾き

(すなわち, ドリル孔自体の傾きと, ドリル孔内でのボ ルトの傾きの和）は最大で3.5であったことから，ドリ ル孔内でのボルトの傾き（最大で $\pm 1.6^{\circ} ）$ を加味しても， 60個全ての供試体においてACI 355.4-11を満足する精度で ドリル削孔ができたものと判断することができる.

アンカーの接着剤が完全に硬化した後, コンクリート 円柱を水平方向に型枠ごとスライスし，これを試験片と した．試験片はコンクリート円柱の上面近傍を避け，1 体につき3枚ずつ採取した。試験片の厚さについてACI 355.4-11では13/16士1/8インチ（27～33.3 mm） と規定して いるが，本研究ではこれに準拠した30 mmと，やや薄い $25 \mathrm{~mm}$ 種類について試験し, 結果を比較した。これ は，カプセル方式の接着系アンカーの場合，製品の寸法 に応じてドリル削孔長に制約があり，スライス試験片の 厚さを30 mmに設定すると, 1本のアンカーからスライ ス試験片を3枚採取するのが困難となる場合があるため である. 接着系アンカー打設後のコンクリート断面と, 試験片採取方法の概略を図-3に示す.

\section{（2）薬液浸せき}

作製した試験片は，プラスチック製水槽に満たした $\mathrm{KOH}$ 水溶液中に浸せきした. 浸せき開始時の母材コン クリートの材齗はおよそ20週である. $\mathrm{KOH}$ 水溶液の濃 度は約1 mol/LでpH 13.2〜13.5程度となるように調製し，

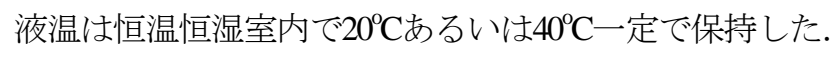
試験片は，互いに30 mm程度の間隔を保つよう，水槽中 に立てて静置した. 浸せき試験時の試験片設置状況を図 -4 に示す.

所定の時間が経過した時点で試験片を取り出し, 軽く 水洗した後，押抜試験を実施した。押抜試験は，試験片 取り出し後から1時間以内に実施した。 ACI 355.4-11の規

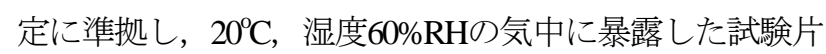
についても同様に評価した，スライス試験片の数量は， 一水準あたり10枚とした。

\section{(3) 押抜試験}

押抜試験の概略図を図-5に示す。押抜試験は，厚さ25 $\mathrm{mm}$ の鋼製反力板で試験片の底面全面を支持し，直径8 $\mathrm{mm}$ 治具により, 試験片上面よりボルト中心に荷重を 加えることにより行った. 反力板の開孔部の直径は16, 17，20，23 mmとし，結果を比較することとした．押抜 試験には万能試験機を用い, 試験速度は $1 \mathrm{~mm} / \mathrm{min}$.で行 った，破壊に至るまでの最大荷重から，式 (1)により接 着強さを求めた.

$$
\tau_{d u r, i}=\frac{N_{u, i}}{\pi d_{a} h_{s l}}
$$

ここに $\tau_{d u r, i}$ : 接着強さ $(\mathrm{MPa}), N_{u, i}$ : 最大荷重 $(\mathrm{N}), d_{a}:$ ア ンカー径 $(\mathrm{mm}), h_{s l}:$ 試験片厚さ $(\mathrm{mm})$

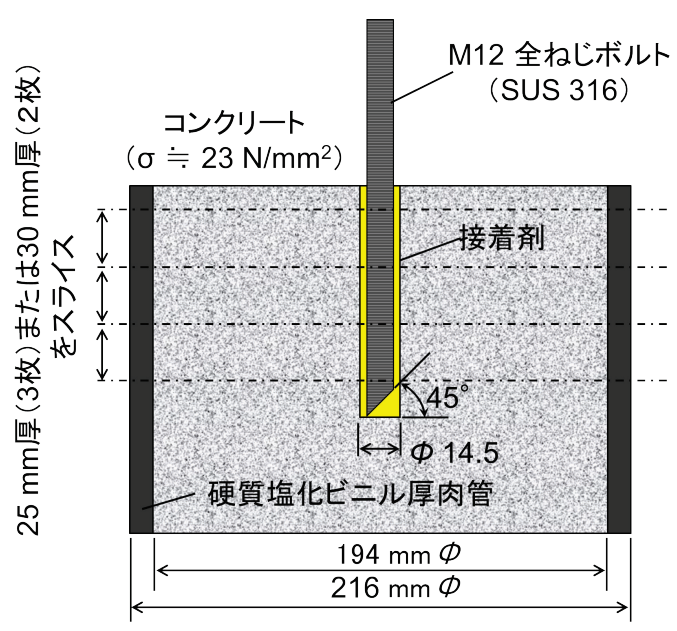

図-3 接着系アンカー打設後のコンクリート断面と試験片採取 方法の概略

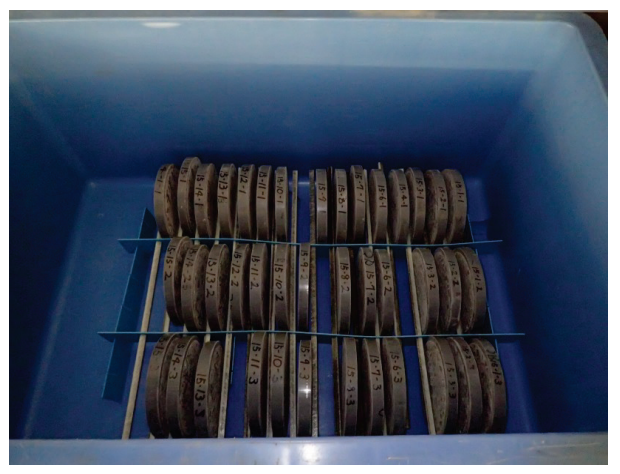

図-4 浸せき試験時の試験片設置状況

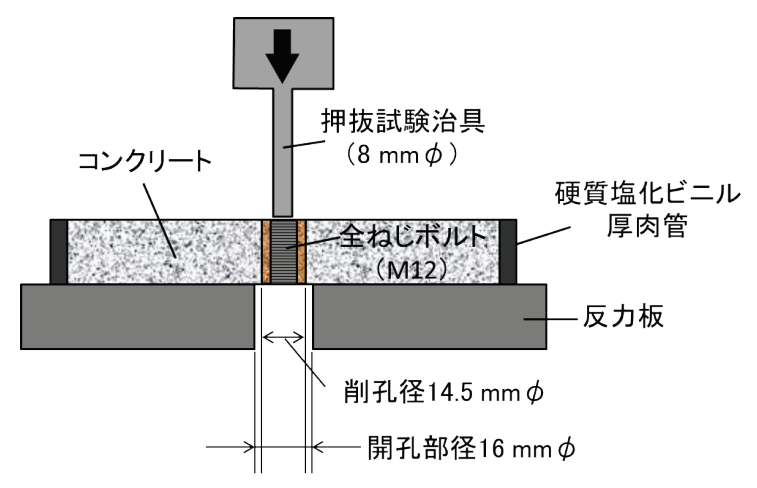

図-5 押抜試験の概略図 


\section{（4）赤外線分光分析}

赤外線分光分析は，有機化合物の中の炭素同士や，炭 素一酸素, 炭素一水素などの化学結合の様々な振動によ る光の吸収が，赤外線域に現れることを利用した化学分 析手法である. 試料の赤外線（波長 $800 \sim 4000 \mathrm{~cm}^{-1}$ 程 度）吸収スペクトルから，樹脂の種類や劣化の有無に関 する情報が得られる ${ }^{4}$ ．そこで，押抜試験後の接着剂の 表面近傍（接着剂表面から深さ数 $10 \mu \mathrm{m}$ 程度までの範 囲）から採取した少量の微粉状のサンプルについて赤外 線分光分析を行い，薬液浸せき前後における接着剤の化 学構造の変化について調べた。

接着剤から得られる微粉状のサンプルには樹脂分と骨 材分とが混合しているため, 光学顕微鏡で観察しながら, 樹脂分と思われる粒子のみを選別し，これをコンプレッ ションセルで加圧圧縮することで赤外顕微鏡を用いた透 過スペクトルの測定を行った.

\section{3. 実験結果と考察}

\section{(1) 押抜試験における試験片厚さの影響}

未浸せきの試験片を用い，押抜試験を実施した．試験 に用いる反力板の開孔部径は $16 \mathrm{~mm}$ とた．押抜試験に おいて，母材コンクリートには肉眼で確認できるひび割 れは生じなかった．試験片の厚さをACI 355.4-11で規定 される範囲内にある $30 \mathrm{~mm}$ と，これよりもやや薄い 25 $\mathrm{mm}$ 種類について試験した結果を図-6に示寸。試験片 厚さが30 mm，25 mmのいずれの場合においても，接着 強さの平均值は11.1 MPaとなった。 厚さ30 mmにおける 標準偏差，変動係数はそれぞれ $2.9 \mathrm{MPa} ， 0.26$ である一方， 厚さ $25 \mathrm{~mm}$ の場合の標準偏差, 変動係数は $3.0 \mathrm{MPa}, 0.27$ であり，ほぼ同じ結果となった。これらの結果に基づき， 以降の実験については，ACI 355.4-11の規定外である25 mm厚の試験を用いて行うこととした.

\section{（2）押抜試験における反力板の開孔部径の影響}

ACI 355.4-11では，押抜試験における反力板の開孔部 径については，特に規定が無い，そこで，未浸せきの試 験片を用い，反力板の開孔部径を変えて押抜試験を実施 した．その結果を図-7に示す．いずれのケースにおいて も，母材コンクリートには肉眼で確認できるひび割れは 生じなかった. 反力板の開孔部径が大きい場合, アンカ 一の接着強さは低くなり, 開孔部径 $16 \mathrm{~mm}$ の接着強さは 平均で11.1 MPaであるのに対し，開孔部径17，20，23 $\mathrm{mm}$ ではいずれも平均で7〜 $8 \mathrm{MPa}$ とった. 開孔部径17, 20，23 mmで試験を行った場合，図-8に示すように，試 験片底面近傍で母材コンクリートが円錐状に破壊する 「コーン状破壊」が認められた。これは，押抜せん断破

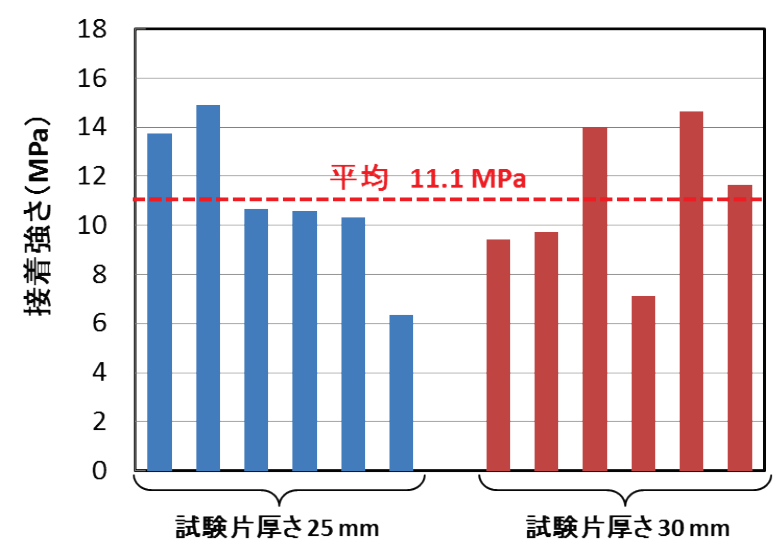

図-6 押拔試験における試験片厚さの影響

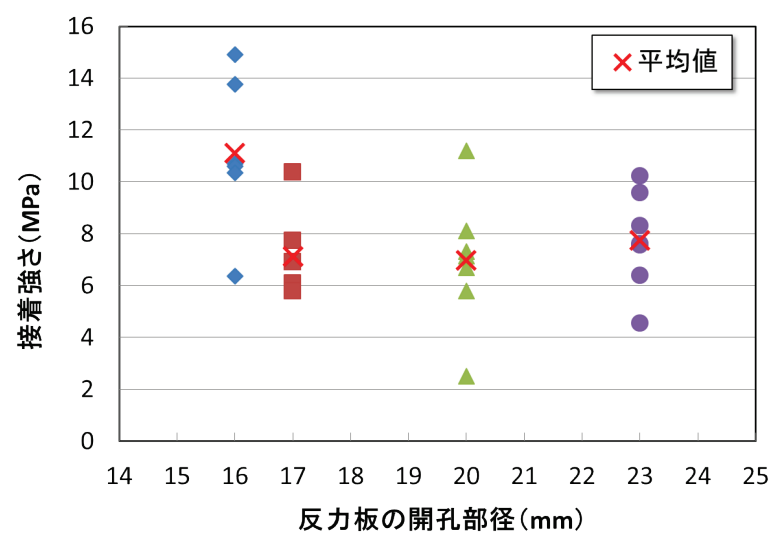

図-7＼cjkstart押抜試験における反力板の開孔部径の影響

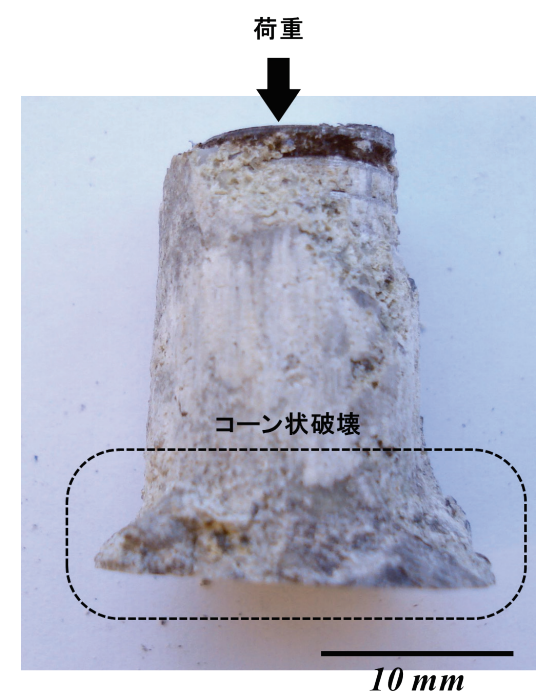

図-8 押抜試験後のアンカーに認められるコーン状破壊（開孔 部径23mm) 
壊において特徵的に見られる破壊形態である.コーン状 破壊部の水平投影面積は反力板の開孔部とほぼ一致して おり，開孔部が大きくなるにつれてコーン状破壊の規模 も大きくなった. このことから，反力板の開孔部径が大 きい場合にはコンクリートの押抜せん断破壊が支配的で あり，これが図-7の結果のように比較的低い荷重での破 壊に繋がったものと考えられる. 高アルカリ環境下にお ける接着剤の劣化を押抜試験によって評価するためには, 接着剤の強度や接着剤とコンクリートとの接着強度を適 切に評価する必要があり, そのためにはコンクリートの 押抜せん断破壊の影響を極力排除する必要がある. 上記 の結果から，コンクリートの押抜せん断破壊の影響を排 除するためには, 反力板の開孔部径を小さく設定するこ とが望ましいと言える．なお，本研究ではドリル削孔径 を14.5 mmとしているが, この場合, 開孔部径を $16 \mathrm{~mm}$ よりも小さくすると，試験時に抜け出したアンカーが開 孔部内壁と干渉してしまう。したがって, 本研究では反 力板の開孔部径を16 mmと設定し，以降の試験を行った.

\section{（3）押抜試験における破壊形態}

押抜試験後の試験片からアンカーを完全に抜き取り， 外観観察を行った結果，接着剤層内で凝集破壊が生じて いる部分と，コンクリート／接着剤の界面破壊が生じて いる部分があった（図-9）。いずれのサンプルにおいて も接着剂の上側（試験片上面側）は凝集破壊しており， 相対するコンクリート母材の孔内には接着剤の破片が接 着したまま残留していた。一方で，接着剤の下側（試験 片底面側）は，接着剤とコンクリートとの界面で破壊し ており, 試験片底面近傍では母材コンクリートの付着が 見られた。

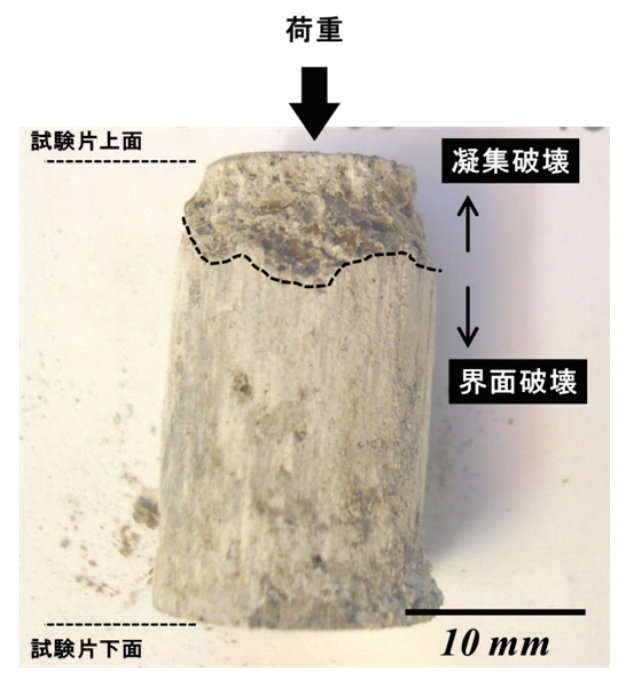

図-9 押抜試験後のアンカーの典型的な外観（開孔部径16 $\mathrm{mm})$
押抜試験で得られた典型的な荷重一変位曲線（図10) では，最大荷重に至るまで滑らかな曲線を示す (A) のパターンと, 試験初期の比較的低い荷重で極值を示寸 (B) のパターンが見られた. (B) を示した試験片では, 試 験初期の比較的低い荷重で接着剤に局部的な破壊が生じ たものと推察される. 押抜試験で得られた全ての荷重一 変位曲線を (A) (B) のパターンに分類し, 最大荷重の区 分毎に該当する試験片数をカウントした結果を図-11に 示す．最大荷重が小さくなるにつれて (B) のパターンの 荷重一変位曲線を示すものの割合が大きくなり, 逆に最 大荷重が $11 \mathrm{kN}$ 超えたものについては全て (A)のパター ンの荷重一変位曲線となった。

押抜試験後のアンカー外観について荷重一変位曲線の パターンに留意して観察したところ, (B) のパターンの 荷重一変位曲線を示したサンプルでは (A) のパターンの ものに比べて, 接着剤の充填不良による空隙箇所が多く

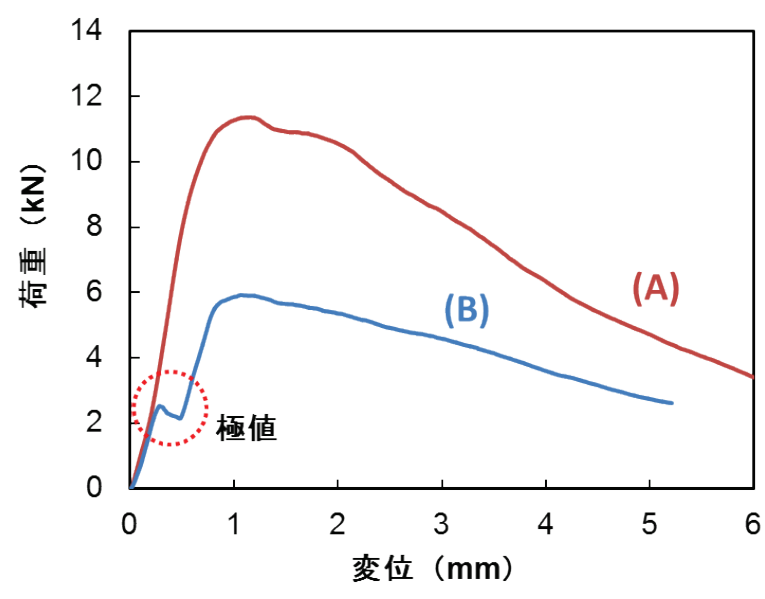

図-10押抜試験における典型的な荷重一変位曲線

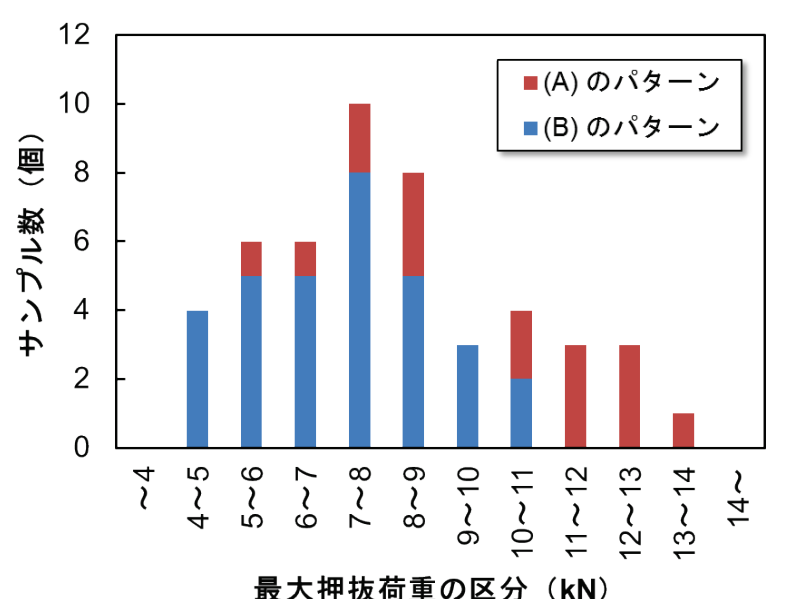

図-11 押抜試験における最大荷重と荷重一変位曲線のパター ンとの関係 


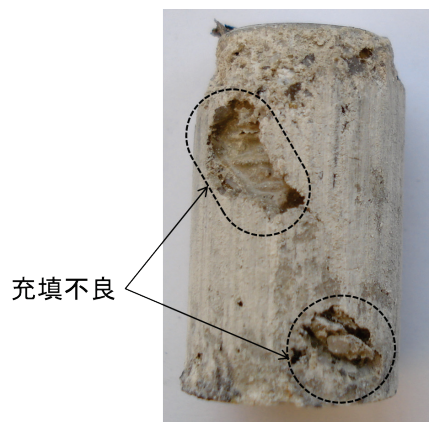

(a) (B)のケース

(最大押拻荷重 $6.9 \mathrm{kN}$ )

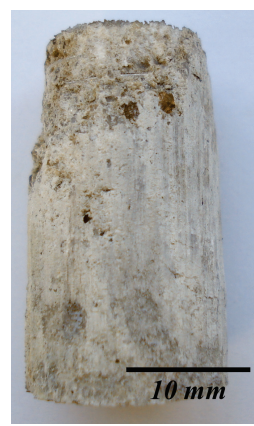

(b) (A)のケース (最大押抜荷重 $12.1 \mathrm{kN}$ )
図-12 押抜試験後のアンカー外観の比較

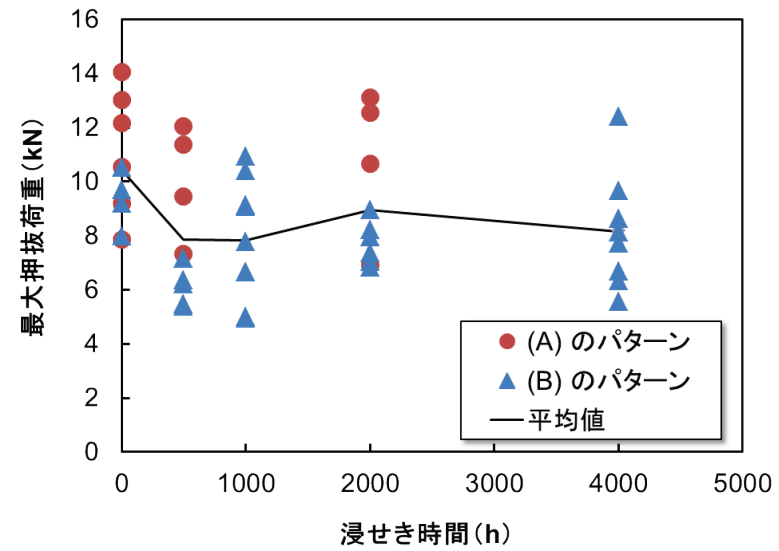

図-13 最大押抜荷重の経時変化 $\left(40^{\circ} \mathrm{C}, \mathrm{pH} 13.2 \mathrm{KOH}\right.$ 水溶液浸せき $)$

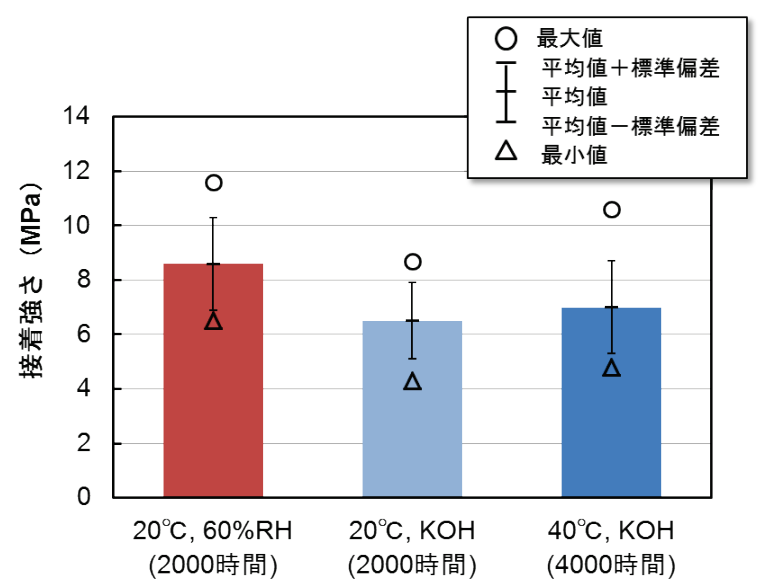

図-14＼cjkstart各環境条件下で浸せき（暴露）後のアンカー接着強さ

間で平均 $6.5 \mathrm{MPa} ， 40^{\circ} \mathrm{C} ， 4000$ 時間で7.0 MPaとなり，環境 液の温度や浸せき時間による差異は明確ではなかった。 気中暴露の試験片でアンカー接着強さがやや高かったの は, 前述のとおり, 押抜試験時における試験片の物理的 な状態の差異によるものであると考えられる.

\section{(5) $\mathrm{KOH}$ 浸せきにおける接着系アンカーの化学的変化}

$\mathrm{KOH}$ 水溶液浸せきによる接着剤の劣化の有無を調心゙ るため，押抜試験後の接着剂破断面表面近傍の樹脂につ いて, 赤外顕微鏡による化学構造分析を行った. 図-15 は $20^{\circ} \mathrm{C}, 60 \% \mathrm{RH} の$ 気中または $40^{\circ} \mathrm{C} の \mathrm{KOH}$ 水溶液中で 2000 時間経過後の, 接着剤表面の赤外吸収スペクトルを示し ている. いずれのスペクトルにおいても $1730 \mathrm{~cm}^{-1}$ 付近に, エステル結合の強い吸収ピークが認められる。これは, 不飽和ポリエステル樹脂のスペクトルの特徵の一つであ る. $40^{\circ} \mathrm{C}$ に浸せきした接着剤のスペクトルでは， 1730 $\mathrm{cm}^{-1}$ 付近の吸収がやや弱まり, $1580 \mathrm{~cm}^{-1}$ 付近に新たな吸 収ピークの出現の兆候が認められた. 既往の研究などか 
ら，不飽和ポリエステル樹脂に含まれるエステル結合が アルカリ存在下で加水分解しカルボン酸塩を生じた場合 に，同様の赤外吸収スペクトルの変化を示すことが明ら かとなっている5). すなわち, 図-15で示したスペクト ルの変化から， $40^{\circ} \mathrm{C}$ KOH水溶液に浸せきしたことによ り，接着剤表面近傍の樹脂が加水分解を生じていること が示唆された． 既往の知見5) 6)よ゙から，加水分解が進 行するほど1580 $\mathrm{cm}^{-1}$ 付近のピークは強くなり，逆に1730 $\mathrm{cm}^{-1}$ 付近の吸収は弱まるものと考えられるため, これら の2つの吸収ピークの比を指標として利用し，浸せきに よる加水分解の程度を評価することにした．方法は以下 のとおりである7.

a) スペクトルを吸光度に換算して解析する.

b) $1580 \mathrm{~cm}^{-1}$ 付近および $1730 \mathrm{~cm}^{-1}$ 付近の吸収ピークそれ ぞれについて, ベースラインからピークトップま での高さを求める. ベースラインは各吸収ピーク の高波数側／低波数側の 2 点のピーク立ち上がり部 を結ぶ直線とする（図-16）。なお，1580 $\mathrm{cm}^{-1}$ 付近 に明確な吸収ピークを持たない試料については,

$1580 \mathrm{~cm}^{-1}$ における吸光度とベースラインとの差をピ ーク高さとする.

c) 上記で求められる $1580 \mathrm{~cm}^{-1}$ 付近 $/ 1730 \mathrm{~cm}^{-1}$ 付近の吸 収ピーク高さの比が当該スペクトルの加水分解度 合いの指標となる. $\left(1580 \mathrm{~cm}^{-1} / 1730 \mathrm{~cm}^{-1}\right.$ 比が大き いほど加水分解が進んでいることとなる．）

赤外吸収スペクトルの解析結果を図-17に示す。それ ぞれのデータは，押抜試験後における接着剤表面の任意 の3か所から試料を採取してスペクトル測定を行い，解 析して得られた結果の平均值を示している. $40^{\circ} \mathrm{C} の \mathrm{KOH}$ 水溶液に浸せきした場合の吸光度比 $\left(1580 \mathrm{~cm}^{-1}\right.$ 付近 / $\left.1730 \mathrm{~cm}^{-1}\right)$ の経時変化に着目すると, 浸せき時間の増加 に伴い，吸光度比も増加していることがわかる. すなお ち, 浸せき時間の増加に伴って, 樹脂の加水分解の程度 が進行する傾向にあることが明らかとなった．2000時間 経過時点の吸光度比について比較すると， $20^{\circ} \mathrm{C}$ 浸せきよ りも $40^{\circ} \mathrm{C}$ 浸せきの方が大きいことから, 環境液の温度が 高い方がより促進的に加水分解が進行しているものと考 えられる. $20^{\circ} \mathrm{C}, 60 \% \mathrm{RH}$ 気中に暴露した試験片について は，2000時間後においても初期とほぼ同程度の吸光度で あることから, 加水分解は生じていないものと推察され る. $40^{\circ} \mathrm{C} の \mathrm{KOH}$ 水溶液では4000時間まで浸せきを継続し たが，この時点においても吸光度比は上昇傾向にあると 考えられることから，引き続き浸せきを継続し，さらに 長期のデータを取得していきたい.

試料ごとに，押抜試験で得られたアンカーの接着強さ と, 赤外吸収スペクトルにおける吸光度比 $\left(1580 \mathrm{~cm}^{-1}\right.$ 付 近 / $1730 \mathrm{~cm}^{-1}$ ) との関係をプロットしたグラフを図-18に 示す. これによると, 本実験からは吸光度比の大小と押

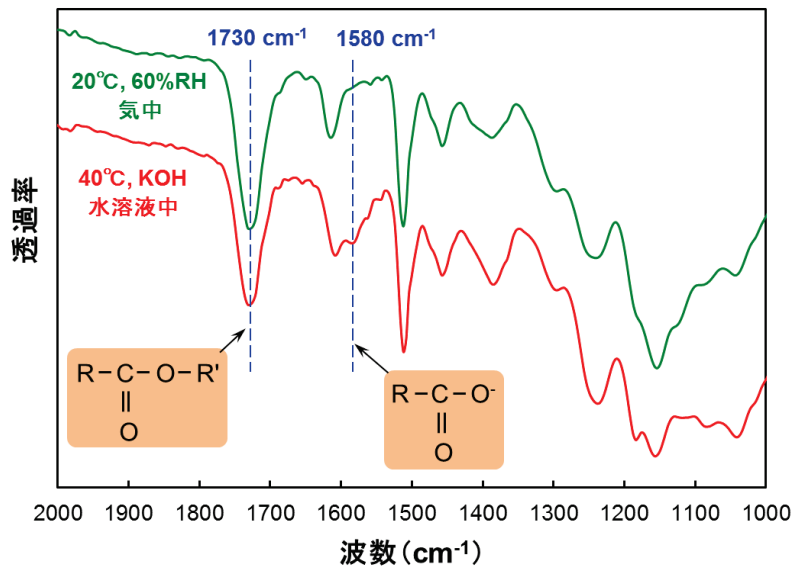

図-15 接着剂表面の典型的な赤外吸収スペクトル（2000時間経過 後)

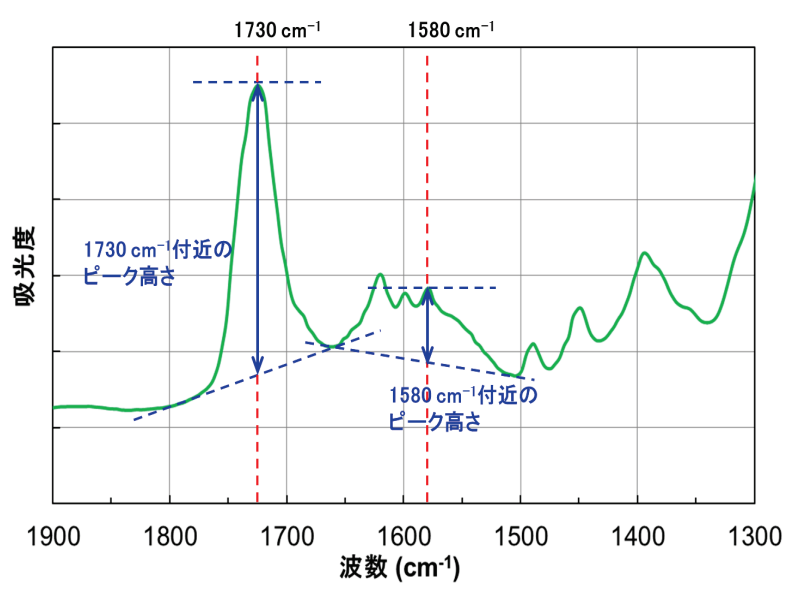

図-16＼cjkstart赤外吸収スペクトルにおけるピーク高さの求め方

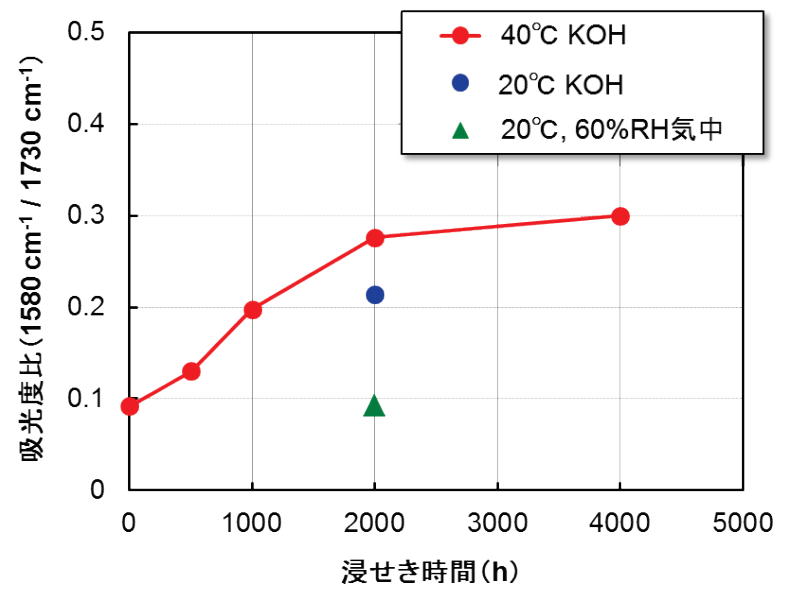

図-17 赤外吸収スペクトルにおける吸光度比の経時変化 $\left(1580 \mathrm{~cm}^{-1}\right.$ 付近 $/ 1730 \mathrm{~cm}^{-1}$ 付近) 


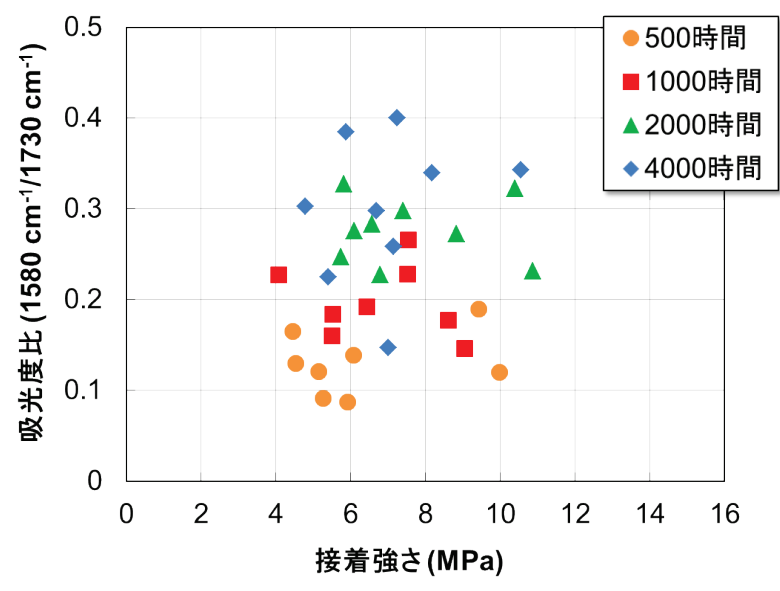

図-18 吸光度比とアンカーの接着強さとの相関 $\left(40^{\circ} \mathrm{C}, \mathrm{KOH}\right.$ 水溶液浸せき)

抜試験による接着強さとの間には，明確な相関が認めら れなかった，その理由の一つとして，押抜試験における 結果のばらつきの大きさ（変動係数20～30\%）が挙げら れる. すなわち, 接着系アンカーの接着強さをアルカリ による劣化の指標として用いるためには，ばらつきを低 減するための試験条件・方法の改良が必要であると思わ れる. 押抜試験結果にばらつきが生じる要因としては, 図-12で示したような接着剤の充填不良や，アンカーと 母材コンクリートとの接着面に位置するコンクリートの 粗骨材の影響等が考えられる. これらの要因による接着 特性への影響は，接着剤の充填不良部の大きさや，コン クリートの骨材粒径に対して，アンカーと母材コンクリ 一トとの接着面積を十分大きくすることにより，低減さ せることが可能であると推察される. すなわち，スライ ス試験片の厚さをより大きく設定したり，アンカーを打 設したままスライスせずに試験に供したりするなど，試 験条件・方法を改良することが望ましいと考えられる.

一方で，本実験では浸せき時間が短く, 接着剤の力学 性能に影響が及ぶほど樹脂の加水分解が進んでいないこ とも考えられることから，今後，さらに長期の浸せきを 行い, アンカーの劣化挙動について引き続きデータを収 集したい.

\section{(6) 接着剂断面の劣化分布}

赤外線分光分析は，接着剂表面の任意の複数箇所から 試料を採取して行ったが，試料採取箇所による吸光度比， すなおち樹脂の加水分解程度の違いは明確ではなかった。 そこで，ATR（減衰全反射）法による接着剤断面の赤外 線分光分析を行い，接着剤の深さ方向について，樹脂の 加水分解の程度をさらに詳細に分析した.

ATR法は，先の尖ったゲルマニウム等のATRクリスタ ルと試料とを密着させ，赤外線をクリスタル／試料界面

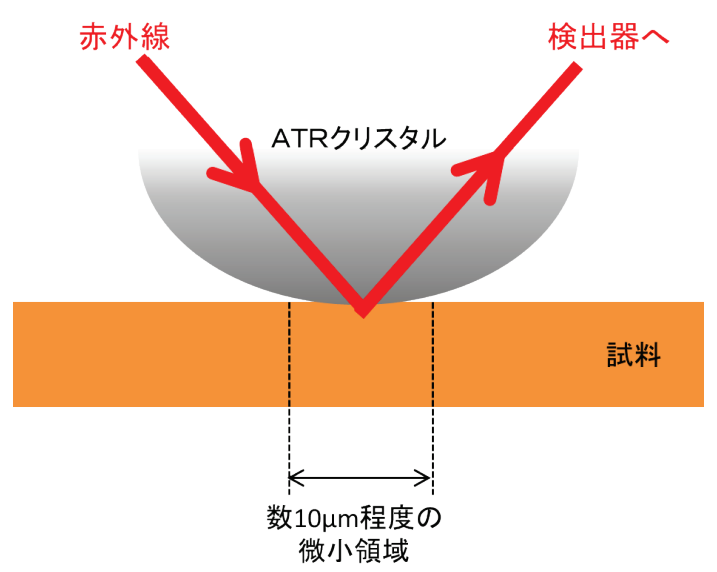

図-19ＡTR法の概略

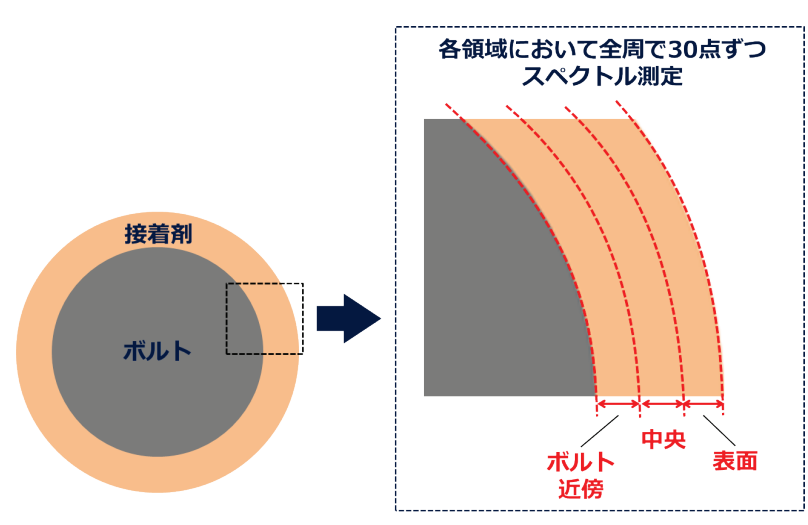

図-20ＡTR法による接着剤断面分析方法の概略

で全反射させたときの反射スペクトルを測定する方法で あり, 数10 $\mu \mathrm{m}$ の微小領域を非破壊で直接分析すること ができる（図-19）。図-17で分析に供したものとは異な るアンカー試料を任意に抽出し，ボルトごと専用の樹脂 で包埋した後，精密切断機を用いてボルトの中心軸に対 しほぼ垂直な平面が得られるようにボルトごとスライス し，分析試料を作製した. 試料の分析面は精密切断機で 切断したまま研磨はせず，純水で軽く洗浄した後に分析 に供した．接着剤表面から接着剤／ボルト界面まで，接 着剂の深さ方向に3つ（接着剂表面, 中央, ボルト近 傍）の領域に区切り，領域ごとにそれぞれ30か所の測定 点を顕微ATR法で測定した。測定点は接着剤断面を光学 顕微鏡で観察し，樹脂と思われる部分から選定した。 こ のとき，それぞれの測定点は，接着剤表面の領域では接 着剂表面から数10４00 $\mu \mathrm{m}$ 程度の範囲，中央の領域では 接着剤表面から 400 800 $\mu \mathrm{m}$ 程度の範囲，ボルト近傍の 領域ではボルトから数 $10 ４ 00 \mu \mathrm{m}$ 程度の範囲となるよう 設定した. 顕微ATR法による接着剤断面の赤外線分光分 析方法の概略について, 図-20に示した. 


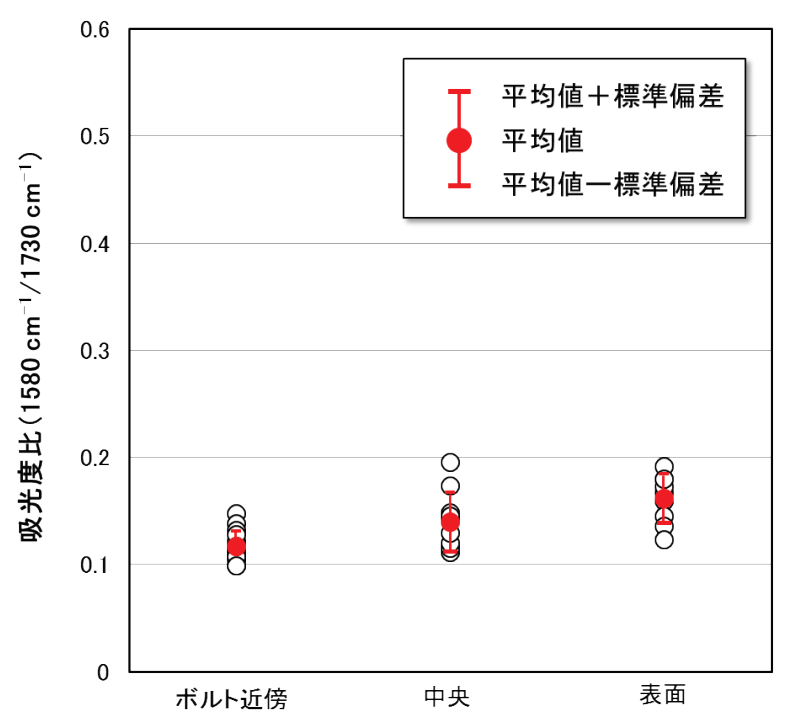

(a) $20^{\circ} \mathrm{C}, 60 \% \mathrm{RH}$ 気中暴露

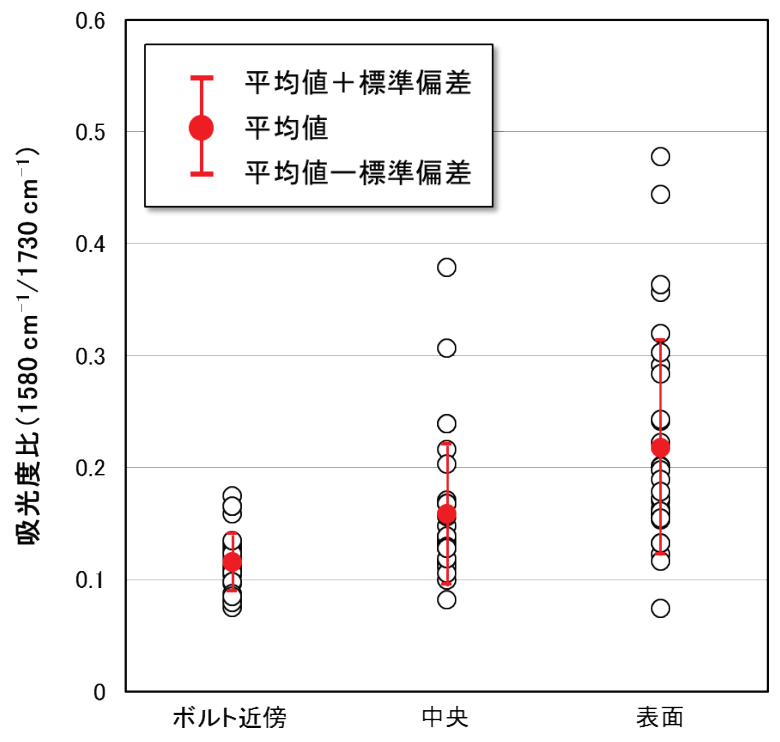

(b) $40^{\circ} \mathrm{C}, \mathrm{KOH}$ 水溶液浸せき

図-212000時間浸せき（暴露）後における接着剤断面の吸光 度比の分布

$20^{\circ} \mathrm{C}, 60 \% \mathrm{RH}$ 気中暴露あるいは $40^{\circ} \mathrm{C}, \mathrm{KOH}$ 水溶液浸せ き2000時間後の接着剤断面について，顕微ATR法により 赤外線分光分析を行った結果を図-21に示す．気中暴露 の場合，深さ方向での吸光度比の変化はほとんど無く， いずれの領域においても0.1〜0.2程度となっている. 一 方， $40^{\circ} \mathrm{C}$ $\mathrm{KOH}$ 水溶液に浸せきした試料については，ボ ルト近傍の領域では気中暴露とほぼ同じ吸光度比を示 したが，表面に近づくにつれて吸光度比の分布は大き くなり，中央では0.1〜0.4程度，表面では0.1〜0.5程度と なった。表面領域における吸光度比の值は図-17で得ら れた值と若干異なっているが，これは分析に供したア
ンカー試料が互いに異なっていること，測定箇所にお ける接着剤表面からの深さが異なる（図-17の場合は接 着剤表面から数 $10 \mu \mathrm{m}$ 程度までをサンプルとして用いて (る）こと，同じ深さで測定した場合においても測定 箇所によって值にばらつきが生じること, などが理由 として考えられる.

接着剤断面の吸光度比の分布から, 気中暴露の接着剤 においては，樹脂の加水分解はほとんど生じていないも のと考えられる.これと同程度の吸光度比を示す箇所が， $\mathrm{KOH}$ 水溶液浸せき後の接着剤表面や中央部にも含まれ ることから，いずれの領域においても樹脂の加水分解が 進行している箇所と，そうでない箇所とが混在した状態 となっているものと思われる. 吸光度比は接着剤表面の 方が中央よりも相対的に大きいことから，この浸せき試 験においては，加水分解による接着剤の劣化は接着剤表 面から内部へと徐々に進行しているものと推察される.

\section{4. まとめ}

本報では，コンクリート内部の高アルカリ環境下にお ける接着系あと施工アンカーの劣化挙動と, その試験評 価方法について検討した結果について報告した。 ACI 355.4-11の試験方法を参考に，水酸化カリウム水溶液一 の浸せきによる接着剤の力学特性の変化を, アンカーの 押抜試験によって評価した。 また，浸せき前後のアンカ 一接着剤について赤外線分光分析を行い, 接着剤の化学 構造の変化を調べた.

実験の結果，40ㄷで4000時間浸せきした場合において も，アンカーの接着強さの明確な低下は認められなかっ た. 一方で，接着剤の樹脂成分である不飽和ポリエステ ルは, 水酸化カリウム水溶液による加水分解が進行しつ つあることが明らかとなった．加水分解の程度は環境液 の温度が高い方が大きく, また, 浸せき時間が長くなる につれ, 接着剤表面から内部へ徐々に進行する挙動を示 した.

加水分解反応の進行程度の指標となる, 赤外吸収スペ クトルの吸光度比の大小は, 押抜試験による接着強さと 明確な相関が認められなかった。この理由の一つとして， 押抜試験における結果のばらつきの大きさが挙げられる. 押抜試験結果にばらつきが生じる要因としては, 接着剤 の充填不良や，アンカーと母材コンクリートとの接着面 に位置する母材コンクリートの粗骨材の影響等が考えら れる.これらの要因による接着特性への影響を低減させ るためには, アンカーと母材コンクリートとの接着面積 を十分大きくすることが望ましいと考えられる. すなわ ち，接着系アンカーの接着強さを指標として，アンカー の劣化を評価するためには, スライス試験片の厚さを大 
きく設定したり，アンカーを打設したままスライスせず に試験したりするなど，ばらつきを低減するための試験 条件や試験方法の改良が必要であると思われる.

今後, より長時間の浸せき試験を行うとともに，異な る樹脂系での試験や分析データを取得し，アルカリ環境 下での接着系アンカーの劣化メカニズムや，ばらつきの 少ない試験評価方法について，さらに詳細に検討してい きたい.

\section{参考文献}

1) ACI 355.4-11: Qualification of Post-Installed Adhesive Anchors in Concrete and Commentary, 2011.

2) 日本建築あと施エアンカー協会 : あと施エアンカー 技術資料 第 7 版, 66 p., 2009.

3）強化プラスチック協会：だれでも使える FRP - FRP
入門 - , pp. 42-55, 2002.

4) 泉 美治, 小川政彌, 加藤俊二, 塩川二朗, 芝 哲夫: 機 器分析のてびき第 2版, pp. 1-23, 化学同人, 1996.

5) Chin, J. W., Aouadi, K., Haight, M. R., Hughes, W. L. and Nguyen, T.: Effects of water, salt solution and simulated concrete pore solution on the properties of composite matrix resins used in civil engineering applications, Polymer Composites, Vol. 22, Issue 2, pp. 282-298, 2001.

6) 富山禎仁, 久保内昌敏, 仙北谷英貴, 津田 健: 高分子 系材料の腐食検知をめざした赤外線透過ファイバセ ンサの特性評価, 強化プラスチックス, Vol. 49, No. 6, pp. 258-264, 2003.

7) トンネル天井板の落下事故に関する調查・検討委員 会: トンネル天井板の落下事故に関する調査・検討委 員会報告書, pp. 29-30, 2013.

(2015. 12. 4 受付)

\section{EXPERIMENTAL STUDY ON ALKALI RESISTANCE OF POST-INSTALLED ADHESIVE ANCHOR}

\section{Tomonori TOMIYAMA and Itaru NISHIZAKI}

The aim of this study was to elucidate the degradation mechanism of post-installed adhesive anchor in alkaline solution and to establish a method for evaluating its alkali resistance properties. We investigated the mechanical properties of the adhesive anchor in potassium hydroxide $(\mathrm{KOH})$ solution with reference to ACI 355.4-11 standard. Changes in chemical structure of the adhesive in the alkaline solution were analyzed with infrared (IR) spectroscopy. The results indicated no significant deterioration in the bond strength of the adhesive after 4000 hours of immersion in $\mathrm{KOH}$ solution at $40^{\circ} \mathrm{C}$. However, unsaturated polyester resin, a component of the adhesive anchor, showed hydrolysis in $\mathrm{KOH}$ solution. The hydrolysis reaction was found to accelerate with increasing temperature of the alkaline solution and progress from the surface to inside with increasing time of immersion. 